OPEN ACCESS

Edited by:

Hongbin Liu,

The Hong Kong University of Science and Technology, Hong Kong

Reviewed by:

Benoit Thibodeau,

University of Hong Kong, Hong Kong Bingzhang Chen,

Japan Agency for Marine-Earth Science and Technology, Japan

*Correspondence:

Nicholas D. Ward nicholas.ward@pnnl.gov

Specialty section:

This article was submitted to Marine Biogeochemistry, a section of the journal Frontiers in Marine Science

Received: 02 November 2016 Accepted: 24 January 2017

Published: 07 February 2017

Citation:

Gagne-Maynard WC, Ward ND, Keil RG, Sawakuchi HO, Da Cunha AC, Neu V, Brito DC, Da Silva

Less DF, Diniz JEM, De Matos Valerio A, Kampel M, Krusche AV and Richey JE (2017) Evaluation of Primary Production in the Lower Amazon River Based on a Dissolved Oxygen Stable Isotopic Mass Balance. Front. Mar. Sci. 4:26 doi: 10.3389/fmars.2017.00026

\section{Evaluation of Primary Production in the Lower Amazon River Based on a Dissolved Oxygen Stable Isotopic Mass Balance}

William C. Gagne-Maynard ${ }^{1}$, Nicholas D. Ward ${ }^{1,2,3 *}$, Richard G. Keil ${ }^{1}$, Henrique O. Sawakuchi ${ }^{1,4}$, Alan C. Da Cunha ${ }^{5}$, Vania Neu ${ }^{6}$, Daimio C. Brito ${ }^{5}$, Diani F. Da Silva Less ${ }^{5}$, Joel E. M. Diniz ${ }^{5}$, Aline De Matos Valerio ${ }^{7}$, Milton Kampel ${ }^{7}$, Alex V. Krusche ${ }^{4}$ and Jeffrey E. Richey ${ }^{1}$

${ }^{1}$ School of Oceanography, University of Washington, Seattle, WA, USA, ${ }^{2}$ Marine Sciences Laboratory, Pacific Northwest National Laboratory, Sequim, WA, USA, ${ }^{3}$ Whitney Laboratory for Marine Bioscience, University of Florida, St. Augustine, FL, USA, ${ }^{4}$ Centro de Energia Nuclear na Agricultura, Universidade de São Paulo, Piracicaba, Brazil, ${ }^{5}$ Departamento de Meio Ambiente e Desenvolvimento, Universidade Federal do Amapá, Macapá, Brazil, ${ }^{6}$ Instituto Sócio Ambiental e dos Recursos Hídricos, Universidade Federal Rural da Amazonia, Belem, Brazil, ${ }^{7}$ Departamento de Sensoriamento Remoto, Instituto Nacional de Pesquisas Espaciais, São José dos Campos, Brazil

The Amazon River outgasses nearly an equivalent amount of $\mathrm{CO}_{2}$ as the rainforest sequesters on an annual basis due to microbial decomposition of terrigenous and aquatic organic matter. Most research performed in the Amazon has been focused on unraveling the mechanisms driving $\mathrm{CO}_{2}$ production since the recognition of a persistent state of $\mathrm{CO}_{2}$ supersaturation. However, although the river system is clearly net heterotrophic, the interplay between primary production and respiration is an essential aspect to understanding the overall metabolism of the ecosystem and potential transfer of energy up trophic levels. For example, an efficient ecosystem is capable of both decomposing high amounts of organic matter at lower trophic levels, driving $\mathrm{CO}_{2}$ emissions, and accumulating energy/biomass in higher trophic levels, stimulating fisheries production. Early studies found minimal evidence for primary production in the Amazon River mainstem and it has since been assumed that photosynthesis is strongly limited by low light penetration attributed to the high sediment load. Here, we test this assumption by measuring the stable isotopic composition of $\mathrm{O}_{2}\left(\delta^{18} \mathrm{O}-\mathrm{O}_{2}\right)$ and $\mathrm{O}_{2}$ saturation levels in the lower Amazon River from Óbidos to the river mouth and its major tributaries, the Xingu and Tapajós rivers, during high and low water periods. An oxygen mass balance model was developed to estimate the input of photosynthetic oxygen in the discrete reach from Óbidos to Almeirim, midway to the river mouth. Based on the oxygen mass balance we estimate that primary production occurred at a rate of $0.39 \pm 0.24 \mathrm{~g} \mathrm{O} \mathrm{m}^{3} \mathrm{~d}^{-1}$ at high water and $1.02 \pm 0.55 \mathrm{~g} \mathrm{O} \mathrm{m}^{3} \mathrm{~d}^{-1}$ at low water. This translates to $41 \pm 24 \%$ of the rate of $\mathrm{O}_{2}$ drawdown via respiration during high water and $67 \pm 33 \%$ during low water. These primary production rates are 2-7 times higher than past estimates for the Amazon 
River mainstem. It is possible that at high water much of this productivity signal is the result of legacy advection from floodplains, whereas limited floodplain connectivity during low water implies that most of this signal is the result of in situ primary production in the Amazon River mainstem.

Keywords: photosynthesis, tropical rivers, respiration, oxygen, mass balance

\section{INTRODUCTION}

A considerable body of work over the last several decades has demonstrated that the world's inland waters are generally supersaturated with carbon dioxide $\left(\mathrm{CO}_{2}\right)$, resulting in a large flux of $\mathrm{CO}_{2}$ from rivers and lakes to the atmosphere (Cole et al., 2007; Battin et al., 2009). This state of supersaturation is driven by the balance between $\mathrm{CO}_{2}$ outputs such as primary production, degassing, and export and $\mathrm{CO}_{2}$ inputs from soils/sediments, the riparian zone, physical and biological decomposition of organic matter $(\mathrm{OM})$ derived from both the terrestrial biosphere (Mayorga et al., 2005; Ward et al., 2013) and aquatic production (Kritzberg et al., 2004; del Giorgio and Pace, 2008), and aquatic plant respiration in floodplains (Abril et al., 2014). Rivers outgas an order of magnitude more $\mathrm{CO}_{2}$ than lakes on a global scale (Raymond et al., 2013). This is commonly attributed to higher rates of primary production relative to respiration in still waters compared to flowing rivers (Tranvik et al., 2009).

Although it is clear that rivers provide a positive flux of $\mathrm{CO}_{2}$ to the atmosphere in most cases, quantifying the relative amount of carbon/energy that is produced vs. consumed in an ecosystem is central to understanding its overall productivity and the potential movement of energy up trophic levels (Odum, 1971). For example, rapid rates of carbon remineralization do not preclude productive fisheries. Lower and higher trophic levels depend on both autochthonous and terrestrial carbon/energy sources to thrive, and the balance in food sources to freshwater ecosystems is tightly linked to hydrology (Hoffman et al., 2008). Likewise, recent evidence has shown that the presence of fresh algal biomass and exudates can stimulate the breakdown of less reactive OM such as terrestrially-derived molecules, implying that systems receiving large inputs of both allochthonous and autochthonous OM are likely highly efficient at recycling carbon (Guenet et al., 2014; Bianchi et al., 2015; Ward et al., 2016).

In large turbid river systems such as the Amazon River it has long been assumed that primary production is minimal relative to heterotrophic respiration due to high sediment loads and low light penetration relative to river depth (Fisher, 1979; Devol et al., 1987; Richey et al., 1990; Hedges et al., 2000). In fact, early measurements of primary production based on ${ }^{14} \mathrm{C}$ uptake indicated rates of primary production that are about an order of magnitude lower than respiration in the Amazon River mainstem, while clearwater tributaries in the basin's lowlands exhibited significantly higher rates of primary production (Wissmar et al., 1981; Benner et al., 1995). However, several studies have more recently found evidence for a higher relative contribution of primary production (and subsequent breakdown of algal OM) to ecosystem metabolism in the Amazon River based on the stable isotopic signature of dissolved oxygen $\left(\delta^{18} \mathrm{O}^{-} \mathrm{O}_{2}\right)$ and the presence of algal biomarkers in the mainstem (Quay et al., 1995; Mortillaro et al., 2011; Ellis et al., 2012). Similar observations of high rates of primary production and algal abundance have also been made in the mainstem of the Congo River, a similar large tropical system (Descy et al., 2017).

These emerging results suggest that there is a large gap between the conventional understanding of production in turbid tropical rivers, and what is actually occurring in the environment. Gross primary production and respiration rates are critical components in understanding the production, transformation and export of $\mathrm{OM}$ and other biogeochemically important nutrients in aquatic ecosystems. The balance between these two is a key measure of the net metabolic state of the ecosystem. As rivers worldwide are saturated with respect to atmospheric $\mathrm{CO}_{2}$ and outgas this $\mathrm{CO}_{2}$ at a massive scale, understanding the exact dynamics of photosynthesis and respiration remain key to understanding the role of river systems in global biogeochemical cycles and have further implications on ecosystem productivity as previously described (Cole and Caraco, 2001; Butman and Raymond, 2011).

The Amazon River is the largest source of freshwater to the world's oceans and outgases $0.5 \mathrm{Pg} \mathrm{C}_{\text {year }}{ }^{-1}$, which is roughly $25 \%$ of recent global estimates (Richey et al., 2002; Raymond et al., 2013). The Amazon River ecosystem also supports the world's most diverse fishery with over 2500 unique species and is among the primary sources of protein for the region (Junk et al., 2007). The massive contribution of the Amazon basin to global biogeochemical cycling and regional economics makes it an ideal setting for evaluating large-scale processes. The lower Amazon River, from Óbidos to the river mouth, is an understudied component of the Amazon basin, but is a region where the interplay between primary production and heterotrophic respiration likely rapidly evolves due to a gradient in environmental conditions (Ward et al., 2016). Most historic measurements of the Amazon River have only been made as far downstream as Óbidos, roughly $800 \mathrm{~km}$ from the mouth of the river (Hedges and Clark, 1986; Quay et al., 1992; MoreiraTurcq et al., 2013). The lower Amazon watershed represents $\sim 13 \%$ of the total drainage basin and is composed of a mixture of wide channels, flooded forests, clear water tributaries and floodplain lakes (Ward et al., 2015). The lower reach of the river is also subject to tidal effects, increasing the residence time of the water and increasing connectivity between flooded forests and the mainstem.

Previous studies have used $\delta^{18} \mathrm{O}-\mathrm{O}_{2}$ values to estimate gas exchange (Jamieson et al., 2012) and estimate net metabolism (i.e., the ratio of respiration to photosynthesis) in steady-state systems (Quay et al., 1995; Bocaniov et al., 2012) as well as non-steady-state systems (Tobias et al., 2007; Holtgrieve et al., 
2010). Past estimates of primary production in the Amazon River are based on a steady-state assumption (i.e., no diel variability in $\delta^{18} \mathrm{O}_{-} \mathrm{O}_{2}$ ) (Quay et al., 1995; Ellis et al., 2012); however, if primary production is actually occurring at appreciable rates in the mainstem of the river this steady-state assumption should not hold true.

This study seeks to examine the occurrence and magnitude of primary production within the lower Amazon River relative to respiration, from the historic downstream gaging station, Óbidos, to the river mouth. Measurements of the concentration and stable isotopic composition of dissolved oxygen made along the lower river and throughout a diel cycle were used to construct an oxygen mass balance for a discreet reach of the system in an effort to determine the relative contribution of primary production and respiration to ecosystem metabolism.

\section{MATERIALS AND METHODS}

Measurements of the concentration and stable isotopic composition of dissolved oxygen were made along the lower
Amazon River and coupled with measurements of microbial respiration rates (Ward et al., unpublished) and gas transfer velocities (Sawakuchi et al., unpublished) made during the same study period to construct an oxygen mass balance for the lower river. The stable isotopic composition of water $\left(\delta^{18} \mathrm{O}-\mathrm{H}_{2} \mathrm{O}\right)$ was also measured for calculations associated with $\delta^{18} \mathrm{O}-\mathrm{O}_{2}$.

\section{Study Area}

Two expeditions were performed along the lower Amazon River during high water (May 2014) and low water (November 2015). The upstream boundary was Óbidos, the historic downstream gaging station, which is roughly $800 \mathrm{~km}$ from the river mouth (Figure 1). The downstream boundary was the northern and southern channels near the city of Macapá (NMCP and SMCP, respectively), which is $\sim 650 \mathrm{~km}$ downstream of Óbidos. Sampling was also performed in the Amazon River mainstem midway to the mouth near the city of Almeirim and near the mouth of the two primary clearwater tributaries downstream of Óbidos, the Xingu and Tapajós rivers. The Tapajós and Xingu rivers add $\sim 10 \%$ to the total discharge of the Amazon River

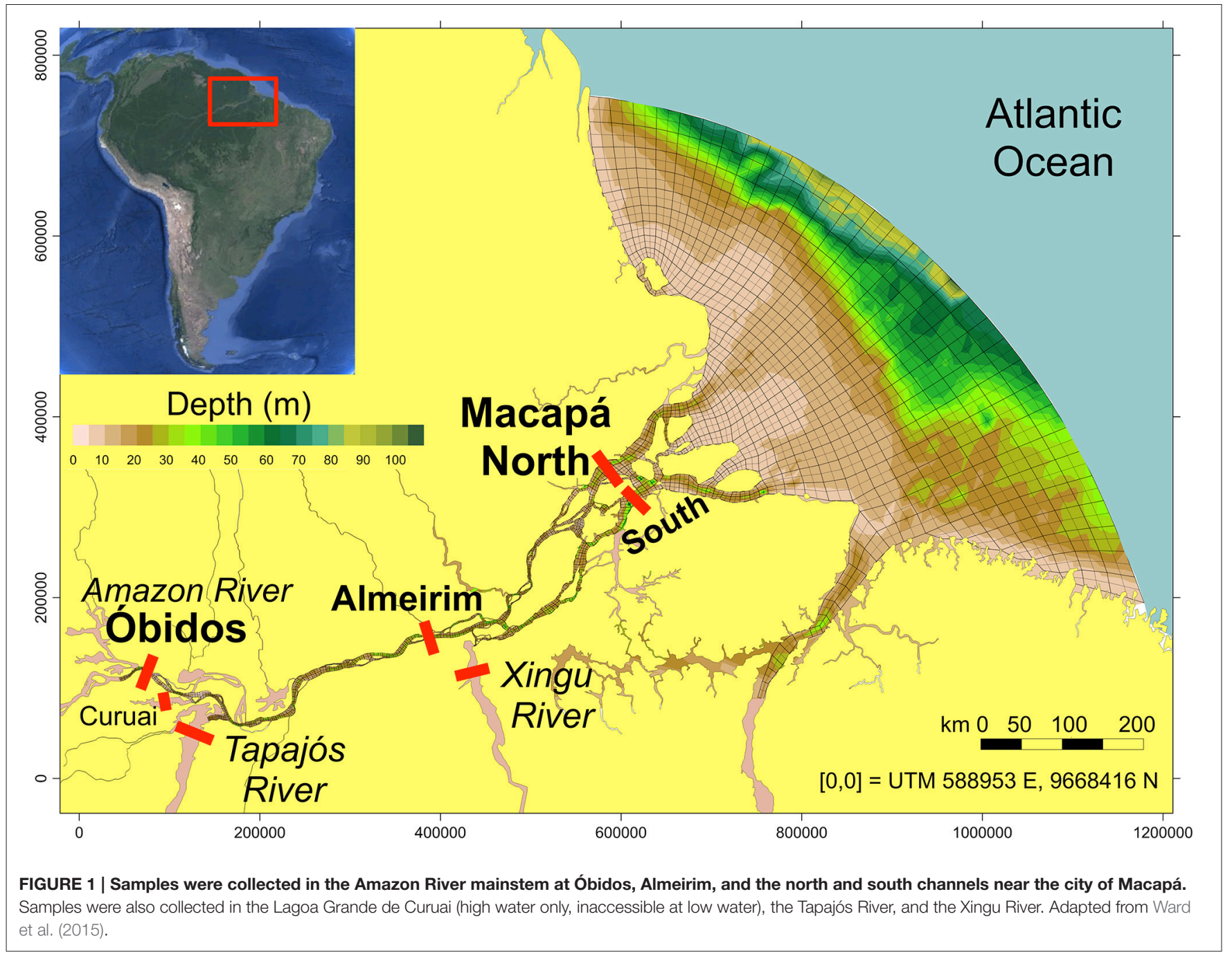


(Sioli, 1985; Molleri et al., 2010). The lower Amazon River is characterized by a mixture of large channels, clear water tributaries, floodplain lakes and flooded forests, representing $\sim 13 \%$ of the total Amazon River drainage basin (Ward et al., 2015). River discharge throughout the study period was reported by Ward et al. (2016) and is also shown in Table $\mathbf{1}$.

\section{Sample Collection}

Water was collected at three equidistant cross-channel sites at each of the five stations on the mainstem (Figure 1) using a Shurflo submersible pump with a $297 \mu \mathrm{m}$ mesh screen at $50 \%$ river depth and from the surface (Ward et al., 2016). Sampling was only performed at one central station in the Tapajós and Xingu rivers at surface and 50\% depth. Only one cross channel station was sampled in these tributaries due to their large channel width and relatively low depth, which results in little variability in chemical parameters across the channel. A graduated cylinder was continuously overflowed without bubbles using the submersible pump. Dissolved $\mathrm{O}_{2}$ concentrations were measured using a YSI ProOdo optical probe submerged in the overflowing cylinder and temperature was similarly measured using a Thermo Orion 4-star meter. Continuous measurements of dissolved $\mathrm{O}_{2}$ concentrations and temperature were also made while the ship was underway using a YSI Exo 2 sonde placed in an overflowing bucket with water pumped from the ship's intake.

Samples were collected for analysis of the stable isotopic composition of water $\left(\delta^{18} \mathrm{O}-\mathrm{H}_{2} \mathrm{O}\right)$ in $15-50 \mathrm{~mL}$ centrifuge tubes and do not require preservation before analysis. Samples were collected for analysis of the stable isotopic composition of dissolved $\mathrm{O}_{2}$ in $12 \mathrm{~mL}$ exetainers (Barth et al., 2004). Four replicate samples were collected at $50 \%$ depth and the surface at all cross channel sites. To assess diel variability in $\mathrm{O}_{2}$ saturation and $\delta^{18} \mathrm{O}-\mathrm{O}_{2}$, surface water samples were collected on a $3 \mathrm{hr}$ interval for $15 \mathrm{~h}$ (evening to morning) at the center of the channel near Óbidos during late high water/early falling water (July, 2015).

Prior to sample collection, exetainers were rinsed with MilliQ water and combusted at $500^{\circ} \mathrm{C}$. Fifty microliters of saturated mercuric chloride was added to each exetainer as a preservative. The exetainers were then dried and flushed with helium gas and capped in a pure helium glove box to remove any trace of atmospheric $\mathrm{O}_{2}$. Samples were collected by immersing the exetainers in the overflowing graduated cylinder. The vials were opened, filled completely, and then capped without removing them from the cylinder to prevent bubbles. To ensure the halt of all biological activity, an additional $50 \mu \mathrm{L}$ of saturated mercuric

TABLE 1 | River discharge, $\mathrm{O}_{2}$ saturation, the stable isotopic composition of dissolved $\mathrm{O}_{2}$, and the stable isotopic composition of $\mathrm{H}_{2} \mathrm{O}$ in the lower Amazon River.

\begin{tabular}{|c|c|c|c|c|c|}
\hline Station/Date & Depth (m) & Discharge $\left(\mathrm{m}^{3} \mathrm{~s}^{-1}\right)$ & [Dissolved $\left.\mathrm{O}^{2}\right]$ (\% saturation) & $\delta^{18}$ O-O 2 (\%o VSMOW) & $\delta^{18} \mathrm{O}-\mathrm{H}_{2} \mathrm{O}$ (\%o VSMOW) \\
\hline \multicolumn{6}{|l|}{ ÓBIDOS } \\
\hline 1-May-14 & 55 & 253,879 & $46.4 \pm 4.8$ & $24.4 \pm 0.6$ & $-5.7 \pm 0.1$ \\
\hline 6-Nov-14 & 51 & 122,274 & $79.2 \pm 1.9$ & $24.0 \pm 0.4$ & $-3.8 \pm 0.2$ \\
\hline Average & 53 & 167,241 & $62.8 \pm 23.2$ & $24.2 \pm 0.3$ & $-4.7 \pm 1.3$ \\
\hline \multicolumn{6}{|l|}{ ALMEIRIM } \\
\hline 4-May-14 & 29 & 298,913 & $53.0 \pm 1.2$ & $25.0 \pm 0.3$ & $-5.4 \pm 0.4$ \\
\hline 10-Nov-14 & 26 & 124,831 & $88.9 \pm 1.8$ & $24.8 \pm 1.5$ & $-3.9 \pm 0.3$ \\
\hline Average & 28 & 207,004 & $71.0 \pm 25.4$ & $24.9 \pm 0.2$ & $-4.7 \pm 1.1$ \\
\hline \multicolumn{6}{|c|}{ NORTH MACAPÁ } \\
\hline 6-May-14 & 19 & 140,624 & $58.1 \pm 1.0$ & $26.5 \pm 1.0$ & $-5.3 \pm 0.4$ \\
\hline 15-Nov-14 & 19 & 61,539 & $93.2 \pm 1.7$ & $23.1 \pm 0.7$ & $-3.0 \pm 0.9$ \\
\hline Average & 19 & 92,200 & $75.6 \pm 24.8$ & $24.8 \pm 2.4$ & $-4.1 \pm 1.6$ \\
\hline \multicolumn{6}{|c|}{ SOUTH MACAPÁ } \\
\hline 9-May-14 & 24 & 204,056 & $59.9 \pm 3.1$ & $24.0 \pm 0.8$ & $-5.2 \pm 0.3$ \\
\hline 14-Nov-14 & 24 & 132,998 & $92.8 \pm 3.5$ & $23.6 \pm 1.0$ & $-3.5 \pm 0.3$ \\
\hline Average & 24 & 146,780 & $76.3 \pm 23.3$ & $23.8 \pm 0.3$ & $-4.4 \pm 1.2$ \\
\hline \multicolumn{6}{|l|}{ CURUAI } \\
\hline 2-May-14 & N.D. & N.D. & $94 \pm 2$ & $23.3 \pm 0.14$ & $-5.3 \pm 0.3$ \\
\hline 7-Nov-16 & N.D. & N.D. & N.D. & N.D. & N.D. \\
\hline \multicolumn{6}{|c|}{ TAPAJÓS RIVER } \\
\hline 2-May-14 & N.D. & 3,658 & $87.4 \pm 7.8$ & $23.9 \pm 0.9$ & $-5.0 \pm 0.1$ \\
\hline 7-Nov-16 & 24 & 10,018 & $94.8 \pm 6.4$ & $23.4 \pm 0.3$ & $-3.8 \pm 0.4$ \\
\hline Average & 24 & 8,052 & $91.1 \pm 5.2$ & $23.7 \pm 0.4$ & $-4.4 \pm 0.8$ \\
\hline \multicolumn{6}{|l|}{ XINGU RIVER } \\
\hline 5-May-14 & 15 & 17,583 & $86.0 \pm 0.6$ & $21.9 \pm 0.5$ & $-3.6 \pm 0.1$ \\
\hline 12-Nov-16 & 15 & 1,650 & $97.3 \pm 0.6$ & $21.0 \pm 0.9$ & $-2.1 \pm 0.3$ \\
\hline Average & 15 & 9,180 & $91.6 \pm 8.0$ & $21.5 \pm 0.6$ & $-2.8 \pm 1.0$ \\
\hline
\end{tabular}


chloride solution was injected through the septa. Septa were then coated with a thin layer of vacuum grease. Samples were analyzed within 2 months at the University of Washington Oceanography Stable Isotope Lab.

\section{Analysis of $\delta^{18} \mathrm{O}-\mathrm{O}_{2}$ and $\delta^{18} \mathrm{O}-\mathrm{H}_{2} \mathrm{O}$}

For $\delta^{18} \mathrm{O}-\mathrm{O}_{2}$ samples pure helium was pumped into the exetainer until half of the water was displaced 1 day prior to analysis. The vials were injected with $50 \mu \mathrm{L}$ of $50 \% \mathrm{H}_{3} \mathrm{PO}_{4}$ to convert all carbonate species to $\mathrm{CO}_{2}$. Isotopic ratios of headspace gases were determined by simultaneously measuring masses 32,34 , and 40 (i.e., ${ }^{16} \mathrm{O}-{ }^{16} \mathrm{O},{ }^{18} \mathrm{O}-{ }^{16} \mathrm{O}$, and ${ }^{40} \mathrm{Ar}$ ) on a Finnegan Delta $\mathrm{XL}$ mass spectrometer (Thermo Electron). Dissolved oxygen concentrations were calculated based on the $\mathrm{O}_{2}$ :Ar ratio (masses 32 and 40) and the estimated dissolved Ar concentration as a function of water temperature (Weiss, 1970). These values were compared to measurements taken with the YSI ProOdo and YSI Exo 2 sonde described above and were roughly equivalent (i.e., within $\sim 5 \%)$. The stable isotopic composition of water $\left({ }^{18} \mathrm{O}-\right.$ $\mathrm{H}_{2} \mathrm{O}$ ) was measured on $15 \mathrm{~mL}$ whole water samples using a Picarro L2130-I Analyzer.

\section{Mass Balance Calculations}

A dissolved oxygen mass balance was calculated for the Amazon River mainstem reach between Óbidos and midway to the mouth near the city of Almeirim (Figure 2). Two mass balance models were developed with the same set of inputs/outputs-one model uses only bulk parameters and the other includes the stable isotopic composition of $\mathrm{O}_{2}$ and associated fractionation factors.

Inputs of $\mathrm{O}_{2}$ included the measured/calculated flux of $\mathrm{O}_{2}$ through Óbidos, measured/calculated $\mathrm{O}_{2}$ fluxes from the Tapajós River (Figure 1), calculated $\mathrm{O}_{2}$ gas exchange with the atmosphere (concentrations in the river were consistently below atmospheric saturation), estimated floodplain inputs, and primary production, which was the unknown parameter that was solved for. $\mathrm{O}_{2}$ outputs included microbial respiration rates measured by Ward et al. (unpublished) and the measured/calculated flux of $\mathrm{O}_{2}$ through Almeirim. In brief, respiration rates were measured in the dark in rotating

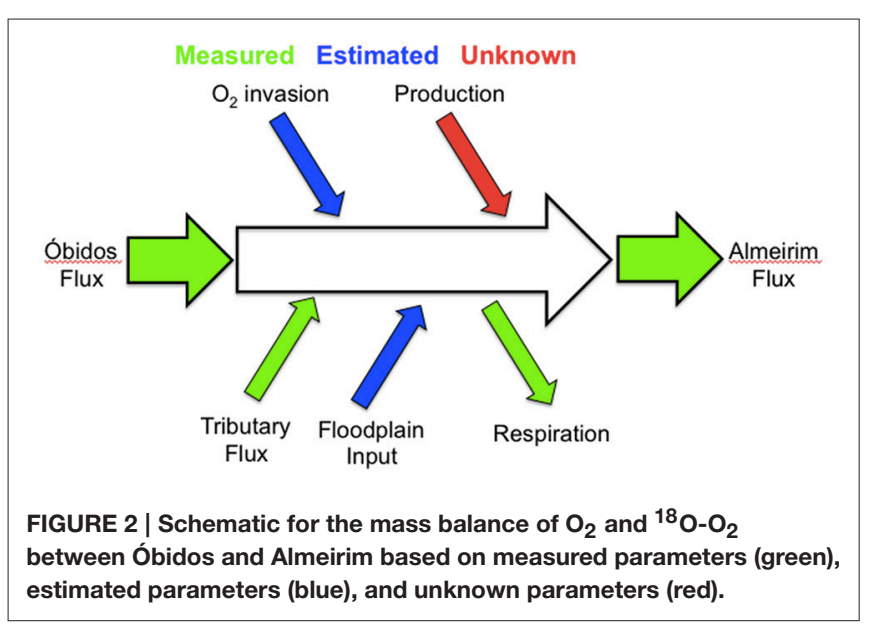

incubation chambers interfaced to an YSI Exo 2 sonde equipped with an optical dissolved $\mathrm{O}_{2}$ probe. Respiration rates were calculated based on the linear drawdown of $\mathrm{O}_{2}$ during a roughly $24 \mathrm{hr}$ period in duplicate $2.85 \mathrm{~L}$ chambers. Respiration rates include uncertainty associated with differences between replicates and averaged sites $( \pm 1$ SD) and an additional $3 \%$ uncertainty due to the lack of inclusion of benthic respiration rates (more details on this in both the results and discussion sections).

This particular section of the river was chosen because the river maintains one well-constrained channel, for the most part, and river flow is not reversed by tides in this reach (although discharge is dampened semi-diurnally at Almeirim). This mass balance was not performed from Almeirim to Macapá because the river becomes extensively channelized and semi-diurnal tidal variation greatly complicates estimations of floodplain connectivity. The uncertainty associated with each mass balance parameter was propagated to our final calculation of primary production.

\section{Calculation of $\mathrm{O}_{2}$ Gas Exchange}

The molecular diffusivity of $\mathrm{O}_{2}$ across the air-water interface is described by the gas transfer velocity parameter $(k)$. Gas transfer velocities can be calculated for other gases (and temperatures) based on the ratio of Schmidt numbers (Sc) (Jähne et al., 1987):

$$
k_{S c 1} / k_{S c 2}=\sqrt{\left(S c_{1} / S c_{2}\right)}
$$

where $k_{S c 1}$ and $k_{S c 2}$ are the gas transfer velocities of a reference gas with a unknown and known value, respectively, and $S c_{1}$ and $S c_{2}$ are the respective Schmidt numbers for each gas. To determine the gas transfer velocity of $\mathrm{O}_{2}$, we converted calculated $k_{\mathrm{CH} 4}$ values that were determined simultaneously (Sawakuchi, unpublished). We calculated $\mathrm{Sc}$ for $\mathrm{O}_{2}$ and $\mathrm{CH}_{4}$ at $28^{\circ} \mathrm{C}$ (measured mean temperature of the water) following Wanninkhof (1992) and used these values and the calculated $k_{\mathrm{CH} 4}$ to determine $k_{\mathrm{O} 2}$.

The flux of a gas across the air-water interface was calculated as follows:

$$
F=k\left(C_{w}-C_{e q}\right)
$$

where $\mathrm{F}$ is flux $\left(\mathrm{mol} \mathrm{m} \mathrm{m}^{-2} \mathrm{~d}^{-1}\right), k$ is the gas transfer velocity $\left(\mathrm{m} \mathrm{d}^{-1}\right), \mathrm{C}_{\mathrm{w}}$ is the concentration of gas measured in the water $\left(\mathrm{mol} \mathrm{m}{ }^{-3}\right.$ ) and $\mathrm{C}_{\mathrm{eq}}$ is the concentration of a water sample at equilibrium with the atmosphere at in situ temperature. Water temperatures ranged from 27.5 to $28.5^{\circ} \mathrm{C}$ over the course of our study. As such, we used a constant value of $28^{\circ} \mathrm{C}$ for all necessary equations. The equilibrium concentration of oxygen at $28^{\circ} \mathrm{C}$ was calculated using Henry's Law. Fluxes were calculated using varied $k$ values calculated as described above, the calculated equilibration concentration and the average concentration of dissolved $\mathrm{O}_{2}$ for this reach of the river during high and low water periods. Uncertainty the gas transfer was calculated as the combination of analytical error and the standard deviation between observations at Óbidos and Almeirim ( \pm 1 SD). 


\section{River Discharge}

The water mass balance for this reach can be described by the following equation:

$$
Q_{O B D}+Q_{T A P}+Q_{f l o o d}=Q_{A L M}
$$

where QOBD is the discharge through Óbidos $\left(\mathrm{m}^{3} \mathrm{~s}^{-1}\right)$, QTAP is discharge from the Tapajós River tributary, $\mathrm{Q}_{\text {flood }}$ is discharge from floodplains, and QALM is discharge through Almeirim. Discharge was measured across the Amazon River main channel at Óbidos and Almeirim and across the mouth of the Tapajós River using a Sontek River Surveyor M9 Portable nine-beam 3.0 MHz/1.0 MHz/0.5 MHz acoustic Doppler Current Profiler (Ward et al., 2015). Discharge from floodplains was estimated by subtracting the measured discharge at Óbidos and the Tapajós River from the measured discharge at Almeirim. It should be noted that this does not necessarily represent the total amount of water that passed through floodplain complexes, but, rather, additional discharge added along this reach of the river from water stored in floodplains.

\section{$\mathrm{O}_{2}$ Mass Balance}

In order to calculate the non-measured/estimated oxygen inputs (i.e., primary production), two mass balance equations were used based on bulk $\mathrm{O}_{2}$ measurements (Equation 4) and both bulk and stable isotopic $\mathrm{O}_{2}$ measurements (Equation 5):

$$
O_{2 A L M}=\frac{\begin{array}{l}
{\left[Q_{O B D} O_{2, O B D}+Q_{T A P} O_{2, T A P}+\right.} \\
\left.Q_{\text {flood }} O_{2, \text { flood }}+A F-V R+V P\right]
\end{array}}{Q_{A L M}}
$$

where $A$ is the area of the river, $F$ is the flux of $\mathrm{O}_{2}$ from the atmosphere to the river, $\mathrm{V}$ is the volume of the river, $\mathrm{R}$ is the average measured respiration rate, and $\mathrm{P}$ is the average rate of primary production, which was solved for. $\mathrm{O}_{2, \mathrm{ALM}}$, $\mathrm{O}_{2, \mathrm{OBD}}, \mathrm{O}_{2, \mathrm{TAP}}$, and, $\mathrm{O}_{2 \text {,flood, }}$ are the measured concentrations of dissolved $\mathrm{O}_{2}$ at Almeirim, Óbidos, the Tapajós River, and the Lagoa Grande de Curuai floodplain lake, respectively. Uncertainty for the flux terms to/from Óbidos, the Tapajós River, and Almeirim are based on the analytical error of the $\mathrm{O}_{2}$ probe, variability in $\mathrm{O}_{2}$ concentrations with depth and across the channel, and discharge measurements ( $\pm 1 \mathrm{SD})$.

Using equation 4 alone can give an estimate of inputs of $\mathrm{O}_{2}$ via primary production between Óbidos and Almeirim, but this can be improved by adding a mass balance for the stable isotopic composition of $\mathrm{O}_{2}$ as follows:

$$
\begin{aligned}
18: 16 O_{2, A L M}= & {\left[Q_{O B D} O_{2, \text { OBD }}{ }^{18: 16} O_{2, \text { OBD }}\right.} \\
& +Q_{\text {TAP }} O_{2, T A P}{ }^{18: 16} O_{2, T A P} \\
& +Q_{\text {flood }} O_{2, \text { flood }}{ }^{18: 16} O_{2, \text { flood }} \\
& +A F^{18: 16} O_{g} \alpha_{g}-V \times R^{18: 16} O_{2} \times \alpha_{R} \\
& \left.+V P^{18: 16} O_{w} \alpha_{P}\right] /\left[Q_{O B D} O_{2, O B D}\right. \\
& \left.+Q_{T A P} O_{2, T A P}+Q_{\text {flood }} O_{2, \text { flood }}+A F-V R+V P\right]
\end{aligned}
$$

where ${ }^{18: 16} \mathrm{O}_{2}$ is the ratio of ${ }^{18} \mathrm{O}$ to ${ }^{16} \mathrm{O}$ calculated from $\delta^{18} \mathrm{O}-\mathrm{O}_{2}$ values for each respective term relative to the Vienna Standard
Mean Ocean Water (VSMOW) standard, ${ }^{18: 16} \mathrm{O}_{\mathrm{g}}$ and ${ }^{18: 16} \mathrm{O}_{\mathrm{w}}$ are the stable isotopic compositions of atmospheric oxygen and river water, respectively. $\alpha_{R}, \alpha_{P}$, and $\alpha_{g}$ are the fractionation factors of respiration, photosynthesis, and gas exchange respectively. A value of 0.982 was used for $\alpha_{R}$, a value of 0.997 was used for $\alpha_{g}$, and a value of 1.000 was used for $\alpha_{P}$ considering $\mathrm{O}_{2}$ produced via primary production reflects the stable isotopic composition of the water (Quay et al., 1995). The above equations were solved for P, or the rate of primary production within this reach. Uncertainty from each model parameter $( \pm 1 \mathrm{SD})$ was propagated through to the final result. All calculations were performed based on the average temperature of $28^{\circ} \mathrm{C}$.

\section{RESULTS}

\section{Dissolved $\mathrm{O}_{2}$ Saturation}

Dissolved oxygen was under-saturated relative to the atmosphere at all sampling locations at both high and low water with an annual average value of $79.3 \pm 18.1 \%$ across the study boundaries. The highest and least variable $\mathrm{O}_{2}$ saturation levels were found in the Tapajós and Xingu clearwater rivers, with seasonal average values of $86.7 \pm 1.0$ and $96.0 \pm 1.8 \%$ at high and low water, respectively (Table 1). The lowest $\mathrm{O}_{2}$ saturation levels were observed during high water in the Amazon River mainstem, specifically at Óbidos. Across all mainstem sites including the mouth, average $\mathrm{O}_{2}$ saturation was $54.3 \pm 6.0 \%$ at high water compared to $88.5 \pm 6.5 \%$ at low water (Table 1).

$\mathrm{O}_{2}$ saturation in the mainstem exhibited a downstream increase from Óbidos to the river mouth with an annual average value of $62.8 \pm 23.2 \%$ at Óbidos, $71.0 \pm 25.4 \%$ at Almeirim, and $76.0 \pm 19.6 \%$. The downstream increase was most evident during low water, with values increasing from $79.2 \pm 1.9 \%$ at Óbidos to $93.0 \pm 0.3 \%$ across the mouth. During the high water period $\mathrm{O}_{2}$ saturation increased from $46.4 \pm 4.8 \%$ at Óbidos to $59.0 \pm 1.3 \%$ across the mouth (Table 1).

The partial pressure of $\mathrm{CO}_{2}$ was previously measured along the same study boundaries (Sawakuchi et al., under review; Ward et al., 2016). There was a negative correlation between the molar concentration of dissolved $\mathrm{O}_{2}$ and $\mathrm{CO}_{2}$ across the study boundaries (Figure 3). Spatial variability of $\mathrm{O}_{2}$ and $\mathrm{CO}_{2}$ in the entire study region, including both the Amazon River mainstem and tributary sites, was higher during the high water period. For example, $\mathrm{CO}_{2}$ concentrations ranged from 86.9 to $200.7 \mu \mathrm{mol} \mathrm{L}{ }^{-1}$ and 36.7 to $61.5 \mu \mathrm{mol} \mathrm{L}^{-1}$ during high and low water, respectively (Figure 3 ). $\mathrm{O}_{2}$ concentrations

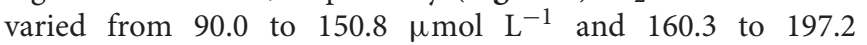
$\mu \mathrm{mol} \mathrm{L}^{-1}$ at high and low water, respectively, across our study boundaries. The slope of the relationship between $\mathrm{O}_{2}$ and $\mathrm{CO}_{2}$ concentrations was 2.2 times higher during low water.

\section{Dissolved $\mathrm{O}_{2}$ Stable Isotopic Composition}

The oxygen stable isotopic composition of water (i.e., $\delta^{18} \mathrm{O}$ $\mathrm{H}_{2} \mathrm{O}$ ) is influenced by isotopic fractionation during each phase of the hydrologic cycle. Annually-averaged $\delta^{18} \mathrm{O}-\mathrm{H}_{2} \mathrm{O}$ was -4.3 $\pm 1.1 \%$ across the entire study boundary. $\delta^{18} \mathrm{O}-\mathrm{H}_{2} \mathrm{O}$ was the most negative in the Amazon River mainstem at high water 


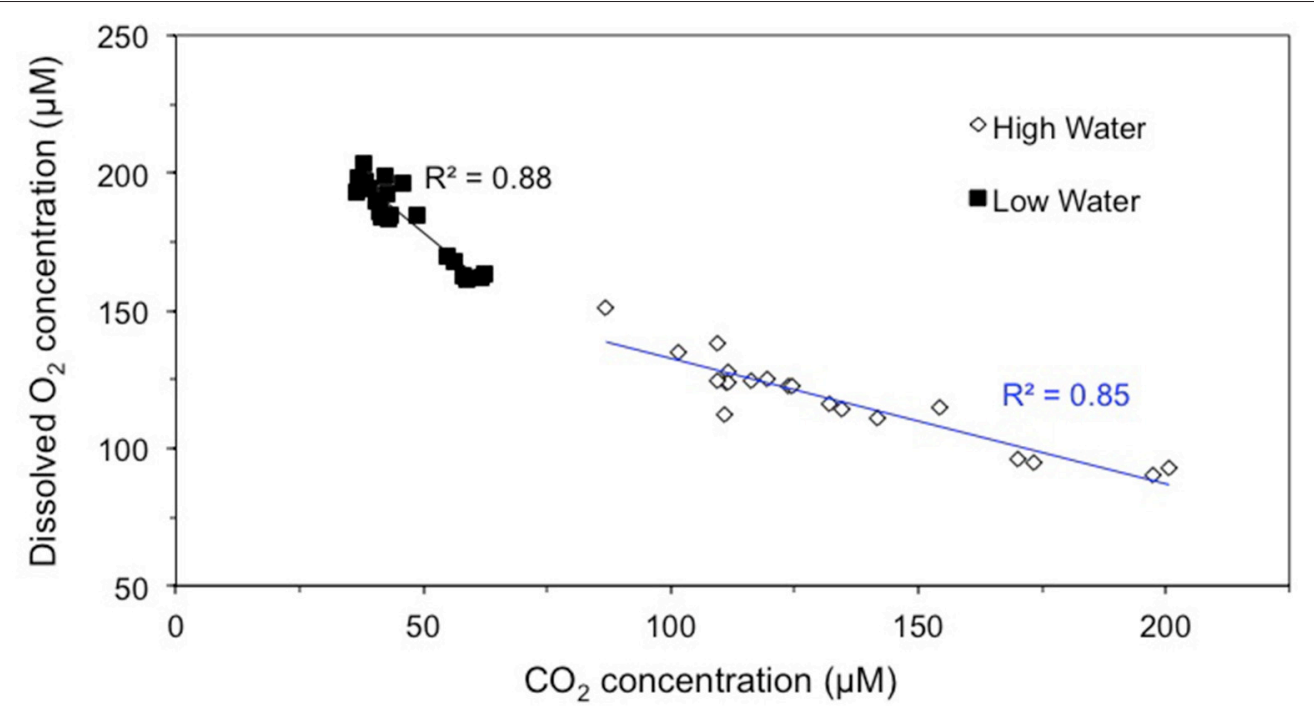

FIGURE 3 | The molar concentration of $\mathrm{CO}_{2}$ vs. $\mathrm{O}_{2}$ at high and low water.

with an average value of $-5.4 \pm 2.1 \%$ compared to $-3.6 \pm$ $0.4 \%$ at low water (Table 1 ). $\delta^{18} \mathrm{O}-\mathrm{H}_{2} \mathrm{O}$ was more positive in the clearwater tributaries (average $=-3.6 \pm 1.2 \%$ ) compared to the Amazon River mainstem (average $=-4.5 \pm 1.0 \%$ ). There was also a downstream increase in $\delta^{18} \mathrm{O}-\mathrm{H}_{2} \mathrm{O}$ from Óbidos to the river mouth. For example, at high water an average $\delta^{18} \mathrm{O}-\mathrm{H}_{2} \mathrm{O}$ value of $-5.7 \pm 0.1 \%$ was observed at Óbidos compared to $-5.2 \pm 0.1 \%$ across the river mouth. The difference between the mainstem and tributaries is likely due to differences in the isotopic composition of rainfall, since much of the water flowing through the mainstem is derived from far upstream.

The annual average stable isotopic composition of dissolved oxygen (i.e., $\delta^{18} \mathrm{O}-\mathrm{O}_{2}$ ) was $23.8 \pm 1.4 \%$ across the entire study boundary. The highest $\delta^{18} \mathrm{O}-\mathrm{O}_{2}$ values were observed in the Amazon River mainstem at high water with an average value of $25.0 \pm 1.1 \%$ o compared to $23.9 \pm 0.7 \%$ o at low water. The clearwater tributaries had consistently lower and less seasonally variable $\delta^{18} \mathrm{O}-\mathrm{O}_{2}$ values, varying from 22.9 $\pm 1.5 \%$ at high water to $22.2 \pm 1.7 \%$ at low water (Table 1). The Xingu River had the lowest $\delta^{18} \mathrm{O}-\mathrm{O}_{2}$ values across all sites (annual average $=21.5 \pm 0.6 \%$ ). $\delta^{18} \mathrm{O}$ $\mathrm{O}_{2}$ and oxygen saturation levels were negatively correlated during both sampling seasons (Figure 4). Higher $\delta^{18} \mathrm{O}-\mathrm{O}_{2}$ values were found at sites with lower oxygen saturation levels and vice versa. The regression slope between $\delta^{18} \mathrm{O}-\mathrm{O}_{2}$ values and oxygen saturation, while following the same trend, was steeper for samples collected at low water compared to water.

It is typically assumed that $\mathrm{d}^{18} \mathrm{O}-\mathrm{O}_{2}$ should remain at steady state in the Amazon River mainstem considering the low levels of light penetration and limited primary production (Quay et al., 1995; Ellis et al., 2012). To test this assumption we measured $\mathrm{O}_{2}$ saturation and $\mathrm{d}^{18} \mathrm{O}-\mathrm{O}_{2}$ throughout a day/night cycle in the center of the channel at Óbidos. While the overall

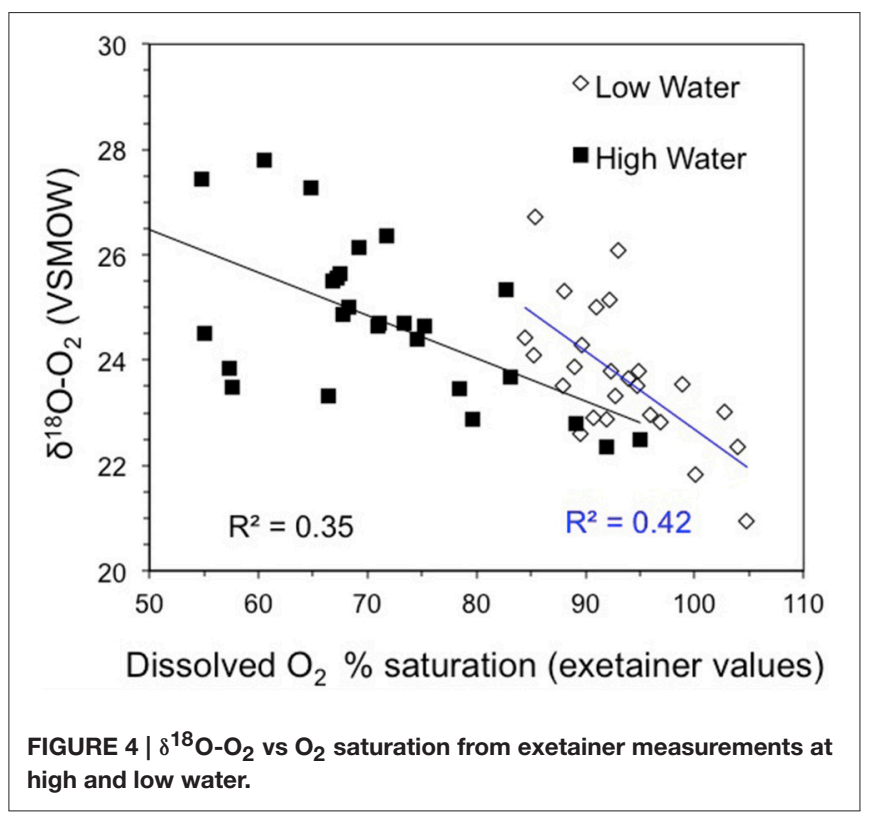

oxygen saturation levels did not vary significantly relative to the signal noise over a $15 \mathrm{hr}$ period, our results indicate that $\mathrm{d}^{18} \mathrm{O}-\mathrm{O}_{2}$ does follow a diel cycle even in the Amazon River mainstem (Figure 5). The minimum $\mathrm{d}^{18} \mathrm{O}-\mathrm{O}_{2}$ was observed at 19:00, roughly $1 \mathrm{~h}$ after sunset $(24.7 \pm 0.6 \%$ o $)$ and the maximum value was observed at 06:00 just prior to sunset (26.4 $\pm 0.3 \%$ o), followed by a decrease to $25.3 \pm 0.7 \%$ at 08:00 (Figure 5). The difference in $\mathrm{d}^{18} \mathrm{O}-\mathrm{O}_{2}$ values observed between midnight and 06:00 and the rest of the diel cycle were statistically significant based on an unpaired $t$-test within a $95 \%$ confidence interval $(p=0.02)$. It should be noted that a complete $24 \mathrm{~h}$ cycle was not able to be captured due to logistical constraints of the field campaign. 


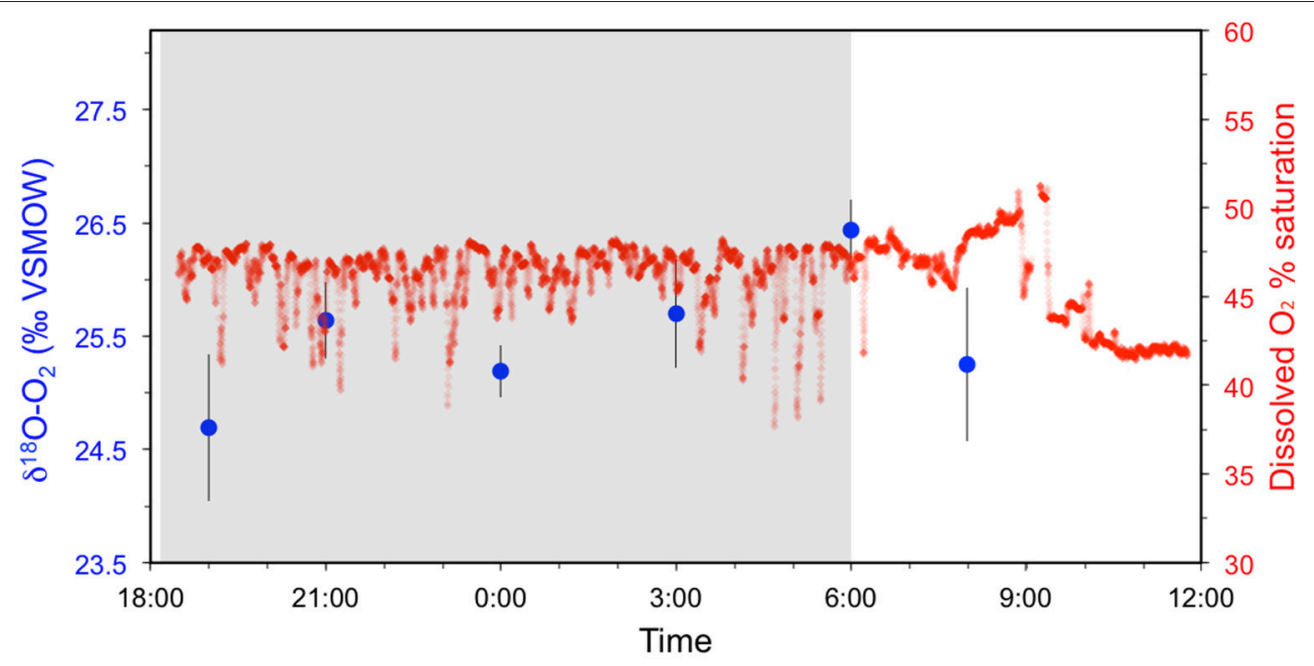

FIGURE 5 | Diel $\mathrm{O}_{2}$ saturation (red) and $\delta^{18} \mathrm{O}-\mathrm{O}_{2}$ (blue) measurements made in the center of the channel at Obidos. The shaded portion of the chart represents hours between sunset and sunrise.

\section{Oxygen Mass Balance Model}

In the past, $\delta^{18} \mathrm{O}-\mathrm{O}_{2}$ values have been used to calculate the ratio of photosynthesis to respiration $(\mathrm{P}: \mathrm{R})$ under a steady state assumption for the Amazon River (Quay et al., 1995; Ellis et al., 2012). However, considering diel variability of $\mathrm{d}^{18} \mathrm{O}-\mathrm{O}_{2}$ was observed, a steady state assumption is not accurate. Thus, in order to determine the rates of photosynthetic oxygen input into the mainstem of the lower Amazon River, we used a mass balance model that takes into account the various sources and sinks of $\mathrm{O}_{2}$ within the system (Figure 2). Because the stable isotopic composition of dissolved $\mathrm{O}_{2}$ is also known, we were able to calculate two separate $\mathrm{O}_{2}$ budgets to model the system based on the following: (1) bulk $\mathrm{O}_{2}$ concentrations only (i.e., Equation 4) and (2) the concentration and stable isotopic composition of $\mathrm{O}_{2}$ (i.e., Equation 5). Including $\mathrm{d}^{18} \mathrm{O}$ $\mathrm{O}_{2}$ observations and literature-derived fractionation factors for each process expressed in Equation 5 resulted in a slight increase in each model parameter compared to the bulk $\mathrm{O}_{2}$ mass balance, however, the resulting calculated P:R ratios were essentially equivalent (Table 2). For this reason, we report the average value for each parameter from these two different models below.

Although $\mathrm{O}_{2}$ concentrations were considerably lower in the Amazon River mainstem during high water (Table 1), the flux of $\mathrm{O}_{2}$ through Óbidos and Almeirim were greater due to higher river discharge rates. The average flux of $\mathrm{O}_{2}$ through Óbidos at high water, determined using both models, was $901 \pm 87 \mathrm{~kg} \mathrm{O} \mathrm{s}^{-1}$ compared to $739 \pm 80 \mathrm{~kg} \mathrm{O} \mathrm{s}^{-1}$ at low water (Table 2). The flux of $\mathrm{O}_{2}$ through Almeirim was consistently greater than at Óbidos, with values of $1228 \pm 112 \mathrm{~kg} \mathrm{O} \mathrm{s}^{-1}$ at high water and $853 \pm 83 \mathrm{~kg}$ $\mathrm{O} \mathrm{s}^{-1}$. This difference was greatest during high water with a $36 \%$ increase in $\mathrm{O}_{2}$ flux from Óbidos to Almeirim compared to a $15 \%$ increase during the low water period.

Aside from primary production, gas exchange was the dominant source of $\mathrm{O}_{2}$ to this reach of the river, resulting in an
TABLE 2 | Dissolved $\mathrm{O}_{2}$ fluxes through Óbidos, Almeirim, floodplains, and the Tapajós River and from respiration, gas exchange, and primary production using mass balance models derived from (1) bulk $\mathrm{O}_{2}$ concentrations and (2) $\mathrm{O}_{2}$ stable isotopic compositions.

\begin{tabular}{|c|c|c|c|c|}
\hline \multirow[t]{2}{*}{ Staion/Process } & \multicolumn{2}{|c|}{$\begin{array}{l}\text { High Water } \mathrm{O}_{2} \text { fluxes } \\
\left(\mathrm{kg} \mathrm{O} \mathrm{s}^{-1}\right)\end{array}$} & \multicolumn{2}{|c|}{$\begin{array}{l}\text { Low Water } \mathrm{O}_{2} \text { fluxes } \\
\text { (Nov. 2014) }\end{array}$} \\
\hline & $\begin{array}{c}\text { Bulk } \mathrm{O}_{2} \\
\text { Model }\end{array}$ & $\begin{array}{c}{ }^{18} \mathrm{O}-\mathrm{O}_{2} \\
\text { Model }\end{array}$ & $\begin{array}{c}\text { Bulk } \mathrm{O}_{2} \\
\text { Model }\end{array}$ & $\begin{array}{c}{ }^{18} \mathrm{O}-\mathrm{O}_{2} \\
\text { Model }\end{array}$ \\
\hline Óbidos (In) & $890 \pm 85$ & $911 \pm 87$ & $731 \pm 82$ & $748 \pm 80$ \\
\hline Tapajós River (In) & $80 \pm 8$ & $81 \pm 10$ & $24 \pm 3$ & $25 \pm 3$ \\
\hline Floodplains (In) & $244 \pm 73$ & $250 \pm 75$ & 0 & 0 \\
\hline Almeirim (Out) & $1,213 \pm 112$ & $1,244 \pm 112$ & $842 \pm 81$ & $863 \pm 83$ \\
\hline Gas Exchange (In) & $714 \pm 166$ & $729 \pm 169$ & $558 \pm 127$ & $571 \pm 130$ \\
\hline Respiration (Out) & $1,210 \pm 173$ & $1,217 \pm 174$ & $1,438 \pm 364$ & $1,455 \pm 368$ \\
\hline Production (In) & $496 \pm 287$ & $489 \pm 291$ & $968 \pm 403$ & $974 \pm 407$ \\
\hline $\mathrm{P}: \mathrm{R}$ ratio & $0.41 \pm 0.24$ & $0.40 \pm 0.25$ & $0.67 \pm 0.33$ & $0.67 \pm 0.33$ \\
\hline
\end{tabular}

Positive values indicate inputs and negative values indicate outputs.

inward flux of $722 \pm 169 \mathrm{~kg} \mathrm{O} \mathrm{s}^{-1}$ at high water and $565 \pm 130 \mathrm{~kg}$ $\mathrm{O} \mathrm{s}^{-1}$ at low water. The Tapajós River provided an additional $81 \pm 10 \mathrm{~kg} \mathrm{O} \mathrm{s}^{-1}$ to the Amazon River mainstem during high water and $25 \pm 3 \mathrm{~kg} \mathrm{O} \mathrm{s}^{-1}$ during low water, which represents about $20-25 \%$ of the difference in fluxes between Óbidos and Almeirim during both seasons. We estimate that the flux of $\mathrm{O}_{2}$ from adjacent floodplains to the mainstem was roughly 247 $\pm 75 \mathrm{~kg} \mathrm{O} \mathrm{s}^{-1}$ during high water (Table 2). At low water, we considered floodplain discharge to be zero considering that river discharge at Almeirim was lower than the sum discharge from Óbidos and the Tapajós River, indicative of water entering and being stored in the floodplains. Further, the Lagoa Grande de Curuai was inaccessible during this sampling period, illustrating the limited floodplain connectivity to the mainstem during this time. 
Aside from the flux through Almeirim, respiration was the primary $\mathrm{O}_{2}$ output. The average water column respiration rate measured across the Amazon River mainstem sampling sites was $0.95 \pm 0.10 \mathrm{~g} \mathrm{O} \mathrm{m}^{3} \mathrm{~d}^{-1}$ at high water and $1.52 \pm 0.35 \mathrm{~g}$ $\mathrm{O} \mathrm{m}^{3} \mathrm{~d}^{-1}$ at low water (Ward et al., unpublished). Benthic respiration rates were not measured, however, literature data is available from sites further upstream. Average benthic respiration rates of $1.46 \mathrm{~g} \mathrm{O} \mathrm{m}^{2} \mathrm{~d}^{-1}$ have been reported for the central Amazon River (Devol et al., 1987). Considering that the average river depth is $\sim 40 \mathrm{~m}$ between Óbidos and Almeirim (Table 1), benthic respiration rates represent only $3 \%$ of depth-integrated water column respiration rates. Since benthic respiration was not measured in our study region, we have included this $3 \%$ error to the uncertainty in our total respiration estimate rather than adding a separate model parameter similar to calculations made by Devol et al. (1987). Water column respiration rates were multiplied by the volume of water between Óbidos and Almeirim $\left(1.09 \times 10^{11} \mathrm{~m}^{3}\right.$ at high water and $8.17 \times 10^{10} \mathrm{~m}^{3}$ at low water $)$, resulting in a consumption of $1228 \pm 112 \mathrm{~kg} \mathrm{O} \mathrm{s}^{-1}$ at high water and $1447 \pm 368 \mathrm{~kg} \mathrm{O} \mathrm{s}^{-1}$ at low water (Table 2).

With all $\mathrm{O}_{2}$ inputs and outputs other than primary production either measured or estimated we then solved for primary production as the difference between the mass balance outputs and inputs. Primary production was estimated to add $492 \pm$ $291 \mathrm{~kg} \mathrm{O} \mathrm{s}^{-1}$ to the Amazon River mainstem between Óbidos and Almeirim at high water and $971 \pm 407 \mathrm{~kg} \mathrm{O} \mathrm{s}^{-1}$. This corresponds to a P:R ratio of $0.41 \pm 0.24$ at high water, 0.67 \pm 0.33 at low water, and $0.54 \pm 0.41$ annually-averaged. When multiplied by the measured respiration rates, this corresponds to a primary production rate of $0.39 \pm 0.24 \mathrm{~g} \mathrm{O} \mathrm{m}^{3} \mathrm{~d}^{-1}$ at high water, $1.02 \pm 0.55 \mathrm{~g} \mathrm{O} \mathrm{m}^{3} \mathrm{~d}^{-1}$ at low water, and $0.70 \pm 0.58 \mathrm{~g} \mathrm{O}$ $\mathrm{m}^{3} \mathrm{~d}^{-1}$ annually-averaged.

\section{DISCUSSION}

\section{Dissolved Oxygen Balance}

The stable isotopic composition of dissolved $\mathrm{O}_{2}$ (i.e., $\delta^{18} \mathrm{O}$ $\mathrm{O}_{2}$ ) is primarily regulated by three processes: air-water gas exchange, respiration, and photosynthesis. In a system purely affected by gas-exchange, the $\delta^{18} \mathrm{O}-\mathrm{O}_{2}$ would be $24.2 \%$ (relative to VSMOW) due to the dissolution of atmospheric $\mathrm{O}_{2}(23.5 \%)$ and the equilibrium fractionation of $0.7 \%$ that occurs during gas dissolution (Kroopnick, 1975; Benson and Krause, 1984). Photosynthesis produces $\mathrm{O}_{2}$ with a $\delta^{18} \mathrm{O}$ of the surrounding water because there is little fractionation observed during photosynthesis (Guy et al., 1993). Respiration selectively fractionates oxygen by consuming $\mathrm{O}_{2}$ that is more depleted than the average, which enriches the remaining pool of $\mathrm{O}_{2}$. Thus, photosynthesis is expected to deplete the $\delta^{18} \mathrm{O}-\mathrm{O}_{2}$ of a system while respiration will enrich the $\delta^{18} \mathrm{O}-\mathrm{O}_{2}$.

Bulk $\mathrm{O}_{2}$ levels were consistently undersaturated relative to the atmosphere across the entire study boundary. Likewise, $\delta^{18} \mathrm{O}-\mathrm{O}_{2}$ values were consistently more enriched in the Amazon River mainstem relative to values expected due to gas transfer with the atmosphere alone (i.e., $24.2 \%$; Table 1), indicating a predominance of respiration relative to photosynthesis. These factors both reflect the net heterotrophic state previously observed in both the Amazon River (Mayorga et al., 2005) and river systems worldwide (Cole et al., 2007), which results in a net flux of $\mathrm{CO}_{2}$ to the atmosphere (Richey et al., 2002; Alin et al., 2011; Raymond et al., 2013).

However, these bulk and stable isotopic $\mathrm{O}_{2}$ observations do not preclude the input of photosynthetically-produced oxygen into the mainstem. In fact, our observations of diel variability in $\delta^{18} \mathrm{O}-\mathrm{O}_{2}$ values at Óbidos clearly indicate a shift in the balance between primary production and respiration in the mainstem throughout a day/night cycle. Our observations were consistent with daytime production depleting $\delta^{18} \mathrm{O}-\mathrm{O}_{2}$ and nighttime respiration enriching the signal, implying that $\mathrm{O}_{2}$ does not remain at a steady-state as previously assumed (Quay et al., 1995; Wassenaar, 2012).

The more depleted $\delta^{18} \mathrm{O}-\mathrm{O}_{2}$ values observed in the Amazon River mainstem during low water indicate a relatively higher amount of primary production relative to respiration during low water. This makes sense considering that suspended sediment concentrations are generally higher during high water in the Amazon River mainstem, limiting primary production (Hedges and Clark, 1986; Moreira-Turcq et al., 2003, 2013).

Respiration rates also vary seasonally, influencing the ratio of production to respiration. The highest respiration rates observed here and in the literature occur during the low water period (Benner et al., 1995; Ellis et al., 2012; Ward et al., 2013), which implies that photosynthesis rates would need to be proportionally higher to achieve a shift in $\mathrm{P}: \mathrm{R}$ ratios during the low water period. In fact, our mass balance model predicted this difference. We estimate that primary production was 2.0 times higher in the Óbidos to Almeirim reach during low water based on our mass balance models (Table 2). Average measured respiration rates were 1.6 times greater in the mainstem during low water, but when integrated across the entire volume of water in the Obidos to Almeirim reach, the total respiration flux was only 1.2 times greater at low water compared to high water. These differences result in the observed shift in the ratio of P:R from $0.41 \pm 0.24$ at high water to $0.67 \pm 0.33$ at low water.

$\mathrm{O}_{2}$ levels were closer to atmospheric saturation in the Tapajós and Xingu rivers (Table 1 ), and $\delta^{18} \mathrm{O}-\mathrm{O}_{2}$ values were below $24.2 \%$ (Table 2), indicating a predominance of primary production relative to respiration in the less turbid clearwater tributaries. Sediment levels are significantly lower in these tributaries compared to the Amazon River mainstem, and high rates of primary production are reflected in elevated chlorophyll $a$ concentrations relative to the Amazon River (Moreira-Turcq et al., 2013; Ward et al., 2015, 2016). Interestingly, respiration rates have been observed to be higher in clearwater tributaries than in the Amazon River mainstem throughout the Amazon basin (Benner et al., 1995; Ellis et al., 2012), yet these tributaries are overall less net heterotrophic. The elevated respiration rates observed in clearwater tributaries have been attributed to both the breakdown of algal organic matter (Benner et al., 1995; Ellis et al., 2012) and the enhanced breakdown of terrestrially-derived organic matter due to priming effects, i.e., the enhanced breakdown of a recalcitrant substrate due to the 
presence of a labile substrate (Bianchi et al., 2015; Ward et al., 2016).

Previous studies have used $\delta^{18} \mathrm{O}-\mathrm{O}_{2}$ values to estimate gas exchange(Jamieson et al., 2012) and estimate net metabolism (e.g., the P:R ratio) in steady-state systems(Quay et al., 1995; Bocaniov et al., 2012) as well as non-steady-state systems (Tobias et al., 2007; Holtgrieve et al., 2010; Hotchkiss and Hall, 2014). For the Amazon River mainstem it has been estimated that the ratio of P:R is roughly 0.25 based on $\delta^{18} \mathrm{O}-\mathrm{O}_{2}$ values and a steady state assumption (Quay et al., 1995), which is 2.2 times lower than our annual average P:R estimate. Primary production rates have also been estimated based on ${ }^{14} \mathrm{C}-\mathrm{NaHCO}_{3}$ uptake experiments; the average rate of primary production was estimated to be $0.10 \pm 0.06 \mathrm{~g} \mathrm{O} \mathrm{m}^{3} \mathrm{~d}^{-1}$ in the Amazon River mainstem and $1.45 \pm 0.75 \mathrm{~g} \mathrm{O} \mathrm{m}^{3} \mathrm{~d}^{-1}$ in the Tapajós and Xingu rivers (Wissmar et al., 1981). This is roughly 6.7 times lower than our mass balance estimates and 2.9 lower than estimates based on multiplying our measured rates of respiration by P:R ratios determined by Quay et al. (1995). We argue that this difference is due to the fact that bottle experiments cannot adequately capture the complex ecosystem dynamics occurring along the entire river reach, whereas a mass balance integrates these signals. Our mass balance results are in agreement with observations of a significant abundance of phytoplankton biomarkers in the mainstem of the Amazon (Mortillaro et al., 2011). Likewise, primary production has recently been found to be important in the main channel of the Congo River (Descy et al., 2017).

\section{Limitations and Future Considerations}

One factor that remains difficult to constrain is whether this input of isotopically depleted $\mathrm{O}_{2}$ is conclusively from in situ production in the mainstem itself or is the legacy of advection from lateral floodplain lakes. These floodplain lakes have high rates of productivity and there is evidence of their legacy biomass in the Amazon mainstem (de Moraes Novo et al., 2006; Abril et al., 2014). This input of floodplain-derived oxygen is reflected in the ratio of $\mathrm{CO}_{2}$ to $\mathrm{O}_{2}$ measured at high and low water (Figure 3). At high water, the ratio is higher, likely due to the input of root respiration-derived $\mathrm{CO}_{2}$ from the floodplains. At high water, these flooded macrophytes draw down oxygen from the atmosphere to their roots, thereby producing $\mathrm{CO}_{2}$ without the concomitant drawdown of $\mathrm{O}_{2}$ from the water column. Thus, it is possible that the isotopically depleted $\mathrm{O}_{2}$ signals observed at high water is actually the legacy of floodplain production and not mainstem production. However, at low water, there is little evidence of macrophyte root respiration as the river loses connectivity with the floodplains. Thus, it is likely the production signal observed at low water is primarily from in situ production within the mainstem rather than floodplains.

Another factor that we did not consider is the importance of benthic respiration from the riverbed. However, past estimates suggest that benthic respiration in the OM-poor sandy sediments only accounts for $\sim 3 \%$ of our measured water column respiration rates (Devol et al., 1987). Thus we did not include a benthic respiration term in our mass balance, but rather added 3\% error to our total respiration term. In some estuarine settings benthic respiration has been shown to be the dominant factor controlling dissolved oxygen concentrations and stable isotopic compositions (Lehmann et al., 2009), however this does not appear to be the case in the fast-flowing, deep river setting where reactive organic matter is highly abundant in the water column but relatively depleted in sediments (Richey et al., 1990; Hedges et al., 2000; Moreira-Turcq et al., 2013).

We did not attempt this same mass balance calculation for the river reach between Almeirim and Macapá due to the complex nature of this region. The river evolves into a series of sub-channels in the lower reaches limiting the applicability of a simplistic model, whereas the reach between Óbidos and Almeirim represents a single, well-constrained channel for the most part. Further, semi-diurnal flow reversals due to tides make it even more difficult to quantify connectivity and import/export from floodplain networks near the river mouth. Future efforts will be applied to unraveling the complex tidally-influenced reach of the river. It should also be noted the floodplain discharge used in this mass balance does not represent the total amount of water that passed through floodplain systems, but, rather, excess water entering the river from floodplains between Óbidos and Almeirim. It is difficult to accurately constrain the amount of water that passes through the Lagoa Grande de Curuai, for example, but this will be the focus of future hydrodynamic modeling efforts to further constrain our mass balance estimates.

\section{CONCLUSIONS}

Early investigations of biogeochemical cycling in the Amazon River found minimal rates of primary production in the turbid mainstem relative to the productive clearwater tributaries (Fisher, 1979; Wissmar et al., 1981). Here, we have shown that there is evidence for primary production within the Amazon River mainstem based on an $\mathrm{O}_{2}$ mass balance, which exceeds past estimates based on a steady-state stable isotopic model by 2.0 times (Quay et al., 1995) and is 6.7 times higher than estimates from radiocarbon uptake experiments (Wissmar et al., 1981). The Amazon River is a major source of $\mathrm{CO}_{2}$ to the atmosphere, but understanding the interplay between photosynthesis and respiration is critical for understanding the fundamental mechanisms driving these fluxes and the overall productivity of the ecosystem. Likewise, in situ primary production has been shown to be an important factor in elevating both bulk respiration rates (Ellis et al., 2012) and the breakdown of terrestrially-derived organic matter (Ward et al., 2016). Although this result does not undermine the idea of the Amazon River as a net heterotrophic system, it does indicate that more work remains to understand the dynamic interplay between production and respiration in large turbid river systems.

\section{AUTHOR CONTRIBUTIONS}

WG performed the collection and analysis of $\delta 18 \mathrm{O}-$ $\mathrm{O}_{2}$ samples and developed the $\mathrm{O}_{2}$ mass balance. 
VN, NW, DD, and JD. performed measurements of dissolved $\mathrm{O}_{2}$ concentrations. $\mathrm{VN}$ and $\mathrm{HS}$. performed estimations of gas transfer velocities used in the mass balance. NW and WG. performed measurements of respiration used in the $\mathrm{O}_{2}$ mass balance. JR, $A D$, and DB performed measurements of river discharge. The field sampling scheme was developed and led by JR, AK, RK, NW, and HS. Field and sampling logistics were undertaken by all authors. All authors contributed to the preparation of the manuscript and approved its final submission.

\section{REFERENCES}

Abril, G., Martinez, J. M., Artigas, L. F., Moreira-Turcq, P., Benedetti, M.F., Vidal, L., et al. (2014). Amazon River carbon dioxide outgassing fuelled by wetlands. Nature 505, 395-398. doi: 10.1038/nature12797

Alin, S. R., Rasera, M. D. F. F. L., Salimon, C. I., Richey, J. E., Holtgrieve, G. W., Krusche, A. V., et al. (2011). Physical controls on carbon dioxide transfer velocity and flux in low-gradient river systems and implications for regional carbon budgets. J. Geophys. Res. Biogeosciences 116:G01009. doi: $10.1029 / 2010$ jg001398

Barth, J. A. C., Tait, A., and Bolshaw, M. (2004). Automated analyses of ${ }^{18} \mathrm{O} /{ }^{16} \mathrm{O}$ ratios in dissolved oxygen from $12-\mathrm{mL}$ water samples. Limnol. Oceanogr. Methods 2, 35-41. doi: 10.4319/lom.2004.2.35

Battin, T. J., Luyssaert, S., Kaplan, L. A., Aufdenkampe, A. K., Richter, A., and Tranvik, L. J. (2009). The boundless carbon cycle. Nat. Geosci. 2, 598-600. doi: $10.1038 /$ ngeo618

Benner, R., Opsahl, S., Chin-Leo, G., Richey, J. E., and Forsberg, B. R. (1995). Bacterial carbon metabolism in the Amazon River system. Limnol. Oceanogr. 40, 1262-1270. doi: 10.4319/lo.1995.40.7.1262

Benson, B. B., and Krause, D. (1984). The concentration and isotopic fractionation of oxygen dissolved in freshwater and seawater in equilibrium with the atmosphere. Limnol. Oceanogr. 29, 620-632. doi: 10.4319/lo.1984.29.3.0620

Bianchi, T. S., Thornton, D. C. O., Yvon-lewis, S. A., King, G. M., Eglinton, T. I., Shields, M. R., et al. (2015). Positive priming of terrestrially derived dissolved organic matter in a freshwater microcosm system. Geophys. Res. Lett. 42, 5460-5467. doi: 10.1002/2015GL064765

Bocaniov, S. A., Schiff, S. L., and Smith, R. E. H. (2012). Plankton metabolism and physical forcing in a productive embayment of a large oligotrophic lake: insights from stable oxygen isotopes. Freshw. Biol. 57, 481-496. doi: $10.1111 / j .1365-2427.2011 .02715 . x$

Butman, D., and Raymond, P., A. (2011). Significant efflux of carbon dioxide from streams and rivers in the United States. Nat. Geosci. 4, 839-842. doi: $10.1038 /$ ngeo1294

Cole, J. J., and Caraco, N. F. (2001). Carbon in catchments: connecting terrestrial carbon losses with aquatic metabolism. Mar. Freshw. Res. 52, 101-110. doi: 10.1071/MF00084

Cole, J. J., Prairie, Y. T., Caraco, N. F., McDowell, W. H., Tranvik, L. J., Striegl, R. G., et al. (2007). Plumbing the Global carbon cycle: integrating Inland waters into the terrestrial carbon budget. Ecosystems 10, 172-185. doi: 10.1007/s10021-006-9013-8

del Giorgio, P. A., and Pace, M. L. (2008). Relative independence of organic carbon transport and processing in a large temperate river: the Hudson River as both pipe and reactor. Limnol. Oceanogr. 53, 185-197. doi: 10.4319/lo.2008.53.1.0185

de Moraes Novo, E. M. L., de Farias Barbosa, C. C., de Freitas, R. M., Shimabukuro, Y. E., Melack, J. M., Filho, W. P., et al. (2006). Seasonal changes in chlorophyll distributions in Amazon floodplain lakes derived from MODIS images. Limnol. 7, 153-161. doi: 10.1007/s10201-006-0179-8

Descy, J. P., Darchambeau, F., Lambert, T., Stoyneva-Gaertner, M. P., Bouillon, S. and Borges, A. V. (2017). Phytoplankton dynamics in the Congo River. Freshw. Biol. 62, 87-101. doi: 10.1111/fwb.12851

\section{FUNDING}

This study was supported by FAPESP Grant \# 08/58089-9 and NSF DEB Grant \# 1256724. WGM was funded by an NSF IGERT grant DGE-1258485.

\section{ACKNOWLEDGMENTS}

We thank the crew of the B/M Mirage for contributions made during the river cruises, Dr. Gordon Holtgrieve for his advice on oxygen isotopes and the Quay Lab at UW for assistance in isotopic analysis.

Devol, A. H., Quay, P. D., and Richey, J. E. (1987). The role of gas exchange in the inorganic carbon, oxygen, and 222Rn budgets of the Amazon River. Limnol. Oceanogr. 32, 235-248. doi: 10.4319/lo.1987.32.1.0235

Ellis, E. E., Richey, J. E., Aufdenkampe, A. K., Krusche, A. V., Quay, P. D., Salimon, C., et al. (2012). Factors controlling water-column respiration in rivers of the central and southwestern Amazon Basin. Limnol. Oceanogr. 57, 527-540. doi: 10.4319/lo.2012.57.2.0527

Fisher, T. R. (1979). Plankton and primary production in aquatic systems of the Central Amazon basin. Comp. Biochem. Physiol. Part A. Physiol. 62, 31-38. doi: 10.1016/0300-9629(79)90739-4

Guenet, B., Danger, M., Harrault, L., Allard, B., Jauset-Alcala, M., Bardoux, G., et al. (2014). Fast mineralization of land-born C in inland waters: first experimental evidences of aquatic priming effect. Hydrobiologia 721, 35-44. doi: 10.1007/s10750-013-1635-1

Guy, R. D., Fogel, M. L., and Berry, J., A. (1993). Photosynthetic fractionation of the stable isotopes of oxygen and carbon. Plant Physiol. 101, 37-47. doi: 10.1104/pp.101.1.37

Hedges, J. I., and Clark, W. A. (1986). Compositions and fluxes of particlate organic material in the Amazon River. Limnol. Oceanogr. 31, 717-738. doi: 10.4319/lo.1986.31.4.0717

Hedges, J. I., Mayorga, E., Tsamakis, E., McClain, M. E., Aufdenkampe, A., Quay, P., et al. (2000). Organic matter in Bolivian tributaries of the Amazon River: a comparison to the lower mainstream. Limnol. Oceanogr. 45, 1449-1466. doi: 10.4319/lo.2000.45.7.1449

Hoffman, J. C., Bronk, D. A., and Olney, J. E. (2008). Organic matter sources supporting lower food web production in the tidal freshwater portion of the York River estuary, Virginia. Estuar. Coast. 31, 898-911. doi: 10.1007/s12237-008-9073-4

Holtgrieve, G. W., Schindler, D. E., Branch, T. A., and Teresa, Z. A. (2010). Simultaneous quantification of aquatic ecosystem metabolism and reaeration using a Bayesian statistical model of oxygen dynamics. Limnol. Oceanogr. 55, 1047-1063. doi: 10.4319/lo.2010.55.3.1047

Hotchkiss, E. R., and Hall R. O. Jr. (2014). High rates of daytime respiration in three streams: Use of $\delta^{18} \mathrm{O}_{\mathrm{O} 2}$ and $\mathrm{O}_{2}$ to model diel ecosystem metabolism. Limnol. Oceanogr. 59, 798-810. doi: 10.4319/lo.2014.59.3.0798

Jähne, B. J., Münnich, K. O. M., Bösinger, R., Dutzi, A., Huber, W., and Libner, P. (1987). On the parameters influencing air-water gas exchange. J. Geophys. Res. 92, 1937-1949. doi: 10.1029/JC092iC02p01937

Jamieson, T. S., Schiff, S. L., and Taylor, W. D. (2012). Using stable isotopes of dissolved oxygen for the determination of gas exchange in the Grand River, Ontario, Canada. Water Res. 47, 781-790. doi: 10.1016/j.watres.2012.11.001

Junk, W. J., Soares, M. G. M., and Bayley, P. B. (2007). Freshwater fishes of the Amazon River basin: their biodiversity, fisheries, and habitats. Aquat. Ecosyst. Health Manag. 10, 153-173. doi: 10.1080/14634980701351023

Kritzberg, E. S., Cole, J. J., Pace, M. L., Grane, W., and Bade, D. L. (2004). Autochthonous versus allochthonous carbon sources of bacteria: results from whole-lake ${ }^{13} \mathrm{C}$ addition experiments. Limnol. Oceanogr. 49, 588-596. doi: 10.4319/lo.2004.49.2.0588

Kroopnick, P. M. (1975). Respiration, photosynthesis, and oxygen isotope fractionation in oceanic surface water. Limnol. Ocean. 20, 981-988. doi: 10.4319/lo.1975.20.6.0988 
Lehmann, M. F., Barnett, B., Gélinas, Y., Gilbert, D., Maranger, R. J., Mucci, A., et al. (2009). Aerobic respiration and hypoxia in the Lower St. Lawrence Estuary: stable isotope ratios of dissolved oxygen constrain oxygen sink partitioning. Limnol. Oceanogr. 54, 2157-2169. doi: 10.4319/lo.2009.54.6.2157

Mayorga, E., Aufdenkampe, A. K., Masiello, C., A., Krusche, A. V., Hedges, J. I., Quay, P. D., et al. (2005). Young organic matter as a source of carbon dioxide outgassing from Amazonian rivers. Nature 436, 538-541. doi: 10.1038/nature03880

Molleri, G. S., Novo, E. M. D. M., and Kampel, M. (2010). Space-time variability of the Amazon River plume based on satellite ocean color. Cont. Shelf Res. 30, 342-352. doi: 10.1016/j.csr.2009.11.015

Moreira-Turcq, P., Bonnet, M. P., Amorim, M., Bernardes, M., Lagane, C., Maurice, L., et al. (2013). Seasonal variability in concentration, composition, age, and fluxes of particulate organic carbon exchanged between the floodplain and Amazon River. Glob. Biogeochem. Cycles 27, 119-130. doi: $10.1002 / \mathrm{gbc} .20022$

Moreira-Turcq, P., Seyler, P., Guyot, J. L., and Etcheber, H. (2003). Exportation of organic carbon from the Amazon River and its main tributaries. Hydrol. Process. 17, 1329-1344. doi: 10.1002/hyp.1287

Mortillaro, J. M., Abril, G., Moreira-Turcq, P., Sobrinho, R. L., Perez, M., and Meziane, T. (2011). Fatty acid and stable isotope $\left({ }^{13} \mathrm{C},{ }^{15} \mathrm{~N}\right)$ signatures of particulate organic matter in the lower Amazon River: seasonal contrasts and connectivity between floodplain lakes and the mainstem. Org. Geochem. 42, 1159-1168. doi: 10.1016/j.orggeochem.2011.08.011

Odum, E. P. (1971). Fundamentals of Ecology. Philadelphia,PA: W.B. Saunders.

Quay, P. D., Wilbur, D., Richey, J. E., Devol, A. H., Benner, R. and Forsberg, B. R. (1995). The ${ }^{18} \mathrm{O}:{ }^{16} \mathrm{O}$ of dissolved oxygen in rivers and lakes in the Amazon Basin: determining the ratio of respiration to photosynthesis rates in freshwaters. Limnol. Oceanogr. 40, 718-729.

Quay, P. D., Wilbur, D. O., Richey, J. E., Hedges, J. I., Devol, A. H., and Victoria, R. (1992). Carbon cycling in the Amazon River: implications from the 13C compositions of particles and solutes. Limnol. Oceanogr. 37, 857-871. doi: 10.4319/lo.1992.37.4.0857

Raymond, P. A., Hartmann, J., Lauerwald, R., Sobek, S., McDonald, C., Hoover, M., et al. (2013). Global carbon dioxide emissions from inland waters. Nature 503, 355-359. doi: 10.1038/nature 12760

Richey, J. E., Hedges, J. I., Devol, A. H., Quay, P. D., Victoria, R., Martinelli, L., et al. (1990). Biogeochemistry of carbon in the Amazon River. Limnol. Oceanogr. 35, 352-371. doi: 10.4319/lo.1990.35.2.0352

Richey, J. E., Melack, J. M., Aufdenkampe, A. K., Ballester, V. M., and Hess, L. L. (2002). Outgassing from Amazonian rivers and wetlands as a large tropical source of atmospheric $\mathrm{CO}_{2}$. 6416, 6413-6416. doi: 10.1038/416617a

Sioli, H. (1985). Amazônia: Fundamentos de Ecologia da Maior Região de Florestas Tropicais. Petrópolis: Editora Vozes.
Tobias, C. R., Böhlke, J. K., and Harvey, J. W. (2007). The oxygen-18 isotope approach for measuring aquatic metabolism in high productivity waters. Limnol. Oceanogr. 52, 1439-1453. doi: 10.4319/lo.2007.52.4.1439

Tranvik, L. J., Downing, J. A., Cotner, J. B., Loiselle, S. A., Striegl, R. G., Ballatore, T. J., et al. (2009). Lakes and reservoirs as regulators of carbon cycling and climate. Limnol. Oceanogr. 54, 2298-2314. doi: 10.4319/lo.2009.54.6_part_ 2.2298

Wanninkhof, R. (1992). Relationship Between Wind Speed and Gas Exchange. J. Geophys. Res. 97, 7373-7382. doi: 10.1029/92JC00188

Ward, N. D., Bianchi, T. S., Sawakuchi, H. O., Gagne-maynard, W., Cunha, A. C., Brito, D. C., et al. (2016). The reactivity of plant-derived organic matter and the potential importance of priming effects along the lower Amazon River. J. Geophys. Res. Biogeosci. 121, 1522-1539. doi: 10.1002/2016jg 003342

Ward, N. D., Keil, R. G., Medeiros, P. M., Brito, D. C., Cunha, A. C., Dittmar, T., et al. (2013). Degradation of terrestrially derived macromolecules in the Amazon River. Nat. Geosci. 6, 530-533. doi: 10.1038/ngeo1817

Ward, N. D., Krusche, A. V., Sawakuchi, H. O., Brito, D. C., Cunha, A. C., Moura, J. M. S., et al. (2015). The compositional evolution of dissolved and particulate organic matter along the lower Amazon River-Óbidos to the ocean. Mar. Chem. 177, 244-256. doi: 10.1016/j.marchem.2015.06.013

Wassenaar, L. I. (2012). Dissolved oxygen status of Lake Winnipeg: spatiotemporal and isotopic $\left(\delta^{18} \mathrm{O}-\mathrm{O}_{2}\right)$ patterns. J. Great Lakes Res. 38, 123-134. doi: $10.1016 /$ j.jglr.2010.12.011

Weiss, R. F. (1970). The solubility of nitrogen, oxygen and argon in water and seawater. Deep Sea Res. Oceanogr. Abstr. 17, 721-735. doi: 10.1016/0011-7471(70)90037-9

Wissmar, R. C., Richey, J. E., Stallard, R. F., and Edmond, J. M. (1981). Plankton metabolism and carbon processes in the Amazon River, its tributaries, and flooplan waters, Peru-Brazil, May-June 1977. Ecology 62, 1622-1633. doi: $10.2307 / 1941517$

Conflict of Interest Statement: The authors declare that the research was conducted in the absence of any commercial or financial relationships that could be construed as a potential conflict of interest.

Copyright $\odot 2017$ Gagne-Maynard, Ward, Keil, Sawakuchi, Da Cunha, Neu, Brito, Da Silva Less, Diniz, De Matos Valerio, Kampel, Krusche and Richey. This is an open-access article distributed under the terms of the Creative Commons Attribution License (CC BY). The use, distribution or reproduction in other forums is permitted, provided the original author(s) or licensor are credited and that the original publication in this journal is cited, in accordance with accepted academic practice. No use, distribution or reproduction is permitted which does not comply with these terms. 